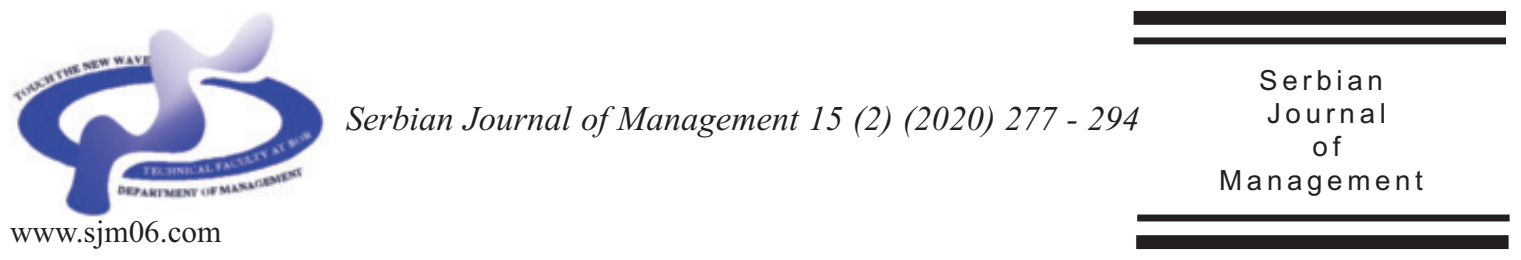

\title{
AN INVESTIGATION OF ONLINE FOOD AGGREGATOR (OFA) SERVICE: DO ONLINE AND OFFLINE SERVICE QUALITY DISTINCT?
}

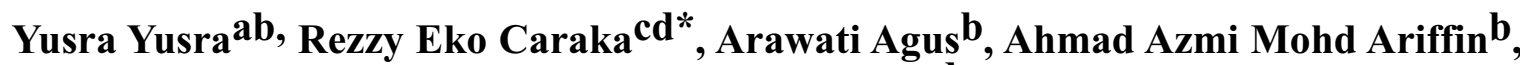 \\ Prana Ugiana Gio ${ }^{e}$, Rung Ching Chend and Youngjo Lee

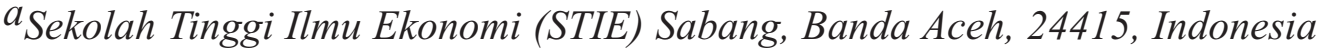 \\ ${ }^{b}$ Universiti Kebangsaan Malaysia, Graduate School of Business, Bangi, 43600, Malaysia \\ ${ }^{c}$ Lab of Hierarchical Likelihood, Research for Basic Sciences, Department of Statistics, \\ Seoul National University, Gwanak-gu, Seoul 08826, Republic of Korea,

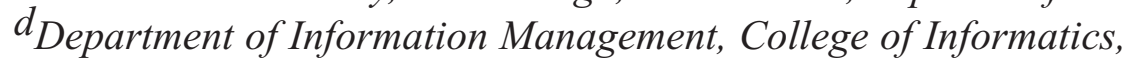 \\ Chaoyang University of Technology, 41349 , Taiwan \\ $e^{e}$ Department of Mathematics, University of North Sumatra, Medan, 20222 , Indonesia
}

(Received 12 January 2020; accepted 09 October 2020)

\begin{abstract}
As the sharing economy has emerged, the way customer perceives the service is shifting toward a combination of offline and online. The need for the service provider to understand its nature as well as the pertinent aspects regarding its characteristics is crucial. Previous research validated the influence of perceived online and offline service quality toward customer satisfaction and loyalty. However, with the distinctive dimensions of OFA service quality, its effects on customer satisfaction and the role of social innovativeness in satisfaction and loyalty linkage remain unexplored. Hence, this study attempts to investigate these relationships using the data obtained from customers of any OFA in Malaysia. Purposive sampling was employed and 227 collected responses were analyzed using variance-based partial least square path modeling. The results confirm the direct effect of online and offline service quality on customer loyalty and full mediation role of customer satisfaction. Besides, social innovativeness is found negatively moderates customer satisfaction and loyalty relationship. Implications and contributions of the study are also discussed.
\end{abstract}

Keywords: online service quality, offline service quality, online food aggregator, customer satisfaction, customer loyalty, social innovativeness

\footnotetext{
*Corresponding author: rezzy94@snu.ac.kr
}

DOI: 10.5937/sjm15-24761 


\section{INTRODUCTION}

Nowadays, people in Malaysia are facing an increasing cost of living in almost every sector (Dhillon, 2019). This mounting budget has upheld those who have idle properties and spare time to undertake these resources to become their new source of extra income (Sundararajan, 2016). This concept then recognized as the sharing economy and has changed the way customer deals with the service provider in commencing their daily life. It has been adopted in transportation, hospitality, and culinary industry and provided benefits, not only for the company but also for the customer who gains the cost and time efficiency. The Malaysian Digital Economy Corporation (MDEC) report shows that sharing economy is estimated to range between US\$700 - 900 million in 2016 and $10-14$ billion in 2025. Therefore, this business model is gaining its popularity in today's business (Belk, 2014).

Sharing economy postulates a variety of advantages for the actors, i.e. consumers, digital platform, and peer service provider (Benoit et al., 2017). For the customer, researchers mostly opined that the apps helps to reduce the hassle for the customer in dealing with the service provider, for example, in ordering food online (Yeo et al., 2017). The ordering process can be classified into two. Firstly, the ordering process is done directly from the restaurant's online food delivery service. This service is characterized by the interaction and transaction process between customer and food provider. The delivery actor is only part of the service from the food provider.

Secondly, the ordering is through online food aggregator. This service provides delivery service from various restaurants.
Using mobile apps, this service provides numerous options of a menu from many restaurants (Kapoor \& Vij, 2018), so that customer may have many options and compare the prices. When placing an order, the customer will be pointed out to the nearest food aggregator rider (peer-service) by the company (digital platform company). Apart from various options, this service also offers the convenience and certitude for the users, as it is featured with, for example, fare estimator and the accessible peer-service (rider) information, such as picture, name, telephone number, and plat number. Thus, our study will focus on online food aggregator, which stipulates the service online and offline.

From the perspective of the peer service provider, the apps brings benefits to operational cost efficiency (Joia \& Altieri, 2018). Equipped with platform-based technology advancement, peer service may reach nearer customers within his location. For instance, this may help to reduce the rider's fuel and time consumption. To join as a peer service provider, for example, Grabfood, the person is not required to have a professional food delivery license to be the rider. Everyone who owns a private motorcycle, motorcycle-license, and smartphone are eligible to join the Grabfood rider. This is unlike taxi drivers who must have a specific license to become ones.

Whilst the service provided in a sharing economy determined OFA has emerged and provided various benefits for the users, especially busy and young adults, there are some unclear characteristics regarding the service (Sutherland \& Jarrahi, 2018). Since the peer service provider in sharing economy is an untrained employee, the efforts to provide superior service to the customer is harder than the professionally trained 
employee. Conversely, to sustain in the market, the company should encourage the peer service provider to provide excellent services in the interest of the customer to sustain in the service (Orel \& Kara, 2014). In this regard, increasing the customer positive response and enhance the company competitiveness, the service quality of OFA should be given more attention and need better understanding. Furthermore, the service delivery process in sharing economy is unique as it involves technology agglomeration and is an interactive process within the customer, peer service provider, and digital platform provider (Benoit et al, 2017). The importance of how customer perceived the service, especially in the OFA setting, is less explored and need a deeper understanding. Therefore, this research aims to uncover these issues and contributes to the body of knowledge by examining the distinguished dimensions of online and offline service quality and its impact on the customer's attitude and behavior.

Moreover, sharing economy involves IT elements and innovation (Priporas et al., 2017). Due to dynamic characteristics of this innovative nature, the personal willingness to seek social status and uniqueness, i.e. social innovativeness, may become an important role in describing the consumer post-purchase behavior (Purani et al., 2019). However, while many studies have been conducted to investigate the customers' attitude toward technology, to the best of our knowledge, the influence of social innovativeness on customer loyalty has not yet been fully addressed. In m-commerce, a customer with high innovativeness is found to be less intention to switch (Lu, 2014). However, this perceptive claim may not be generalized to social innovativeness; therefore, it needs to be explored further.
Furthermore, the distinctive level of these individual characteristics in formatting segmentation in sharing economy and its dynamic effects are also less explored and need for further investigation. Thus, this study aims to address this issue and fulfills the gap, especially in the context of a sharing economy driven OFA.

This study adopts the quantitative and cross-sectional approach using adapted previous service quality scale as the instrument to capture the perceived online and offline service quality. Firstly, we proceed with an introduction and the objectives of the study. Secondly, we briefly discuss the literature review. Thirdly, we describe the conceptual framework that comprises the conceptual model and hypothesis regarding online and offline service quality, customer satisfaction, customer loyalty, and social innovativeness according to evidence related to these constructs correlations. Fourthly, we continue with the methodology used in this study. Fifthly, we highlight the results of the analysis using a website-based statistical application, STATCAL. Finally, we discuss the results and highlight the implications of the study.

\section{LITERATURE REVIEW}

\subsection{Service quality, customer satisfaction, customer loyalty}

Service quality is defined as "a form of attitude, which is related but not equivalent to customer satisfaction, and results from a comparison of expectations with perceptions of performance" (Parasuraman et al, 1985). Literature provides an extensive description regarding service quality (Zeithaml et al., 
1996; Brady \& Cronin Jr, 2001; Parasuraman et al., 2005; Huang et al., 2015; Park et al., 2018). Nonetheless, the gap model and seminal work of Parasuraman (1985: 1988) have become the most raised and cited in the service quality literature. They build SERVQUAL that comprises some dimensions namely, tangibles, reliability, assurance, empathy, and responsiveness. Numerous researches have confirmed the factors comprised in this model and its effect on customer's attitude and behavior (Juwaheer, 2004; Kuo et al., 2009; SetóPamies, 2012). Yet, due to the advancement of sharing economy and technology, this model may need modification and adjustment.

In light of technological advancement, especially smartphone, the service quality literature has incorporated the online-based factors, for example, system quality (Salameh et al., 2018), privacy (Huang et al., 2015), interaction quality (Heo \& Kim, 2017), platform responsiveness, and structural assurance (Cheng et al., 2018). Drawing from sharing-economy concept, the interaction between customer, peer service, and digital platform provider in OFA is not fully conducted online; it requires some offline attributions, e.g., riders. Although the mobile online system is a must to operationalize an OFA, the offline-based attributes should have remained an important consideration, (Cheng et al., 2018). However, to the best of our knowledge, it is scarce in online food aggregator's literature. Hence, our study aims to investigate online and offline service quality concurrently.

Previous researchers have proposed the set of dimensions in operationalize both online and offline service quality. For instance, Cheng et al. (2018) in ride sharing industry and Shao, Li, Guo and Zhang,
(2020) in bicycle ordering platform. However, it is argued that these dimensions are industry-specific and may fail to apply in other online-based industry without alteration (e.g: online food aggregator). To apply these existing frameworks into this research, we have ensured that the items and dimensions selected in the framework are adequate with the service quality of the OFA study. In this present study regard, online service quality is measured by operating three dimensions, namely structural assurance, platform responsiveness, design quality and three dimensions for offline system, namely information congruity, competence, and empathy. The operational definitions of these variables are presented below.

Adapted from ride-sharing research by Cheng et al. (2018), structural assurance is the extent to which customer being assured that the privacy, safety, and security when performing the transaction with the company are guaranteed. Platform responsiveness refers to the extent to which the platform's ability to assist the users in promptly response of their inquiry. While, design quality refers to the extent to which OFA keep its platform's aesthetics, the tempting visualization as well as its ease of use, efficient and simplicity (Heo et al., 2017).

Besides, in the regards of offline service quality, information congruity deals with what exposed in the platform is in line with what it showed physically. Competence is the capability of the peer service provider (the driver) to deliver food and reach the customer comfortably (Cheng et al., 2018). Lastly, empathy refers to the willingness of the driver to help customer and enthusiastic in giving their best performance (Parasuraman et al., 1988). 
In many business sectors, the postadoption evaluation of customer's perception regarding the service performance plays a significant role to online consumers attitude and behavior (Vesel \& Zabkar, 2009; Roos \& Hahn, 2017;). In line with the expectancy disconfirmation paradigm (Oliver, 1980), the consumer's expectations regarding the service perceived from OFA's performance influence the confirmation or disconfirmation of their satisfaction level. For instance, the consumer attitude and behavior toward the service is formed by the set of evaluation. More specifically in online food service, Kapoor and Vij (2018) stated that mobile apps attributes affect the purchase decision, and this attitude consequently leads to the intention to repurchase and purchasing behavior (Cho et al., 2018). However, this mechanism in literature neglects the presence of rider's role as an important actor to whom customer directly deals with during delivery task. Therefore, based on the arguments aforementioned, we hypothesized:

H1a: online service quality positively influences customer satisfaction

H1b: offline service quality positively influences customer satisfaction

H2a: online service quality positively influences customer loyalty

$H 2 b$ : offline service quality positively influences customer loyalty

H3: customer satisfaction positively influences customer loyalty

The existing literature has also highlighted the existence of mechanisms between service quality and customer loyalty. However, there are inconsistencies in the results of the mechanisms. Some of them confirm the full mediation role of customer satisfaction in various environment, e.g., banking (Caruana, 2002; Makanyeza \& Chikazhe, 2017), car-sharing (Cheng et al., 2018), and airlines (Yusra \& Agus, 2018). Conversely, Suhartanto et al. (2018) claimed that customer satisfaction in online food delivery plays a partial mediating role in the relationship between e-service quality and customer loyalty. These inconsistencies promote further confirmation regarding the role of customer satisfaction as mediation variable, especially in online food aggregator settings. Thus, we hypothesized:

H4a: Customer satisfaction mediates the relationship between offline service quality and customer loyalty

H4b: Customer satisfaction mediates the relationship between online service quality and customer loyalty

\subsection{Social Innovativeness}

According to the conservation of resources paradigm, socially stress will motivate human to maintain their existing resources and pursue new resources. Social innovativeness refers to innate innovativeness and needs for being unique and different by which they gain status and social rewards (Vandecasteele \& Geuens, 2010). In fact, the personal factors are among the main predictors in refining the product evaluation (Shah et al., 2018). In this regard, a consumer with a high degree of innovativeness tries to differentiate himself from others. For instance, this characteristic needs for being unique and different (SadikRozsnyai \& Bertrandias, 2019). The innovation of service in ordering food and by using innovative apps virtual interface may be an opportunity for them to do so (Yusra \& Agus, 2020). As such, in order to maintain 
their social status, the consumer will have a tendency to reuse the service although it will charge a higher price (Sadik-Rozsnyai \& Bertrandias, 2019).

With the dynamic characteristics of innovative service and the fast-changing in technology advancement, the consumer behavioral motivation toward the service is likely turbulent. Some researchers believe that the positive relationship of customer satisfaction-loyalty is generalizable within m-commerce setting (Cronin et al., 2000; Santoso \& Nelloh, 2017; Hult et al., 2019). However, some acknowledge that customer continuance behavior may be influenced by personal motivational factors (Dick \& Basu, 1994; Ahn \& Seo, 2018), e.g., social innovativeness.

Social innovativeness is defined as the motivation to adopt new products or services to fulfill a need for uniqueness (SadikRozsnyai \& Bertrandias, 2019). For instance, social innovativeness is a self-reported consumer innovativeness motivated by the self-assertive social need for differentiation (Vandecasteele \& Geuens, 2010). It associated with the motivation of being individuality, independence, superiority, unique, special, and winning of social status. To do so, customer pursues resources to distinguish himself from others that may lead to the inconsistency in an attitude-behavior linkage (Lu, 2014). In addition, due to the dynamic environment of technology-based services and the expansion of digital marketing system, the customer may tremendously be exposed to the attractive offer from other players (Mittal, 2016). It will potentially attract more people to use this service, even though this consumer segment is less price-sensitive (Chuah et al., 2017). As a result, this innovative characteristic will no longer be unique and different. Hence, the relationship between customer satisfaction and loyalty will be adversely induced by the level of social innovativeness. Therefore, by deliberating the above-aforementioned perspective, we hypothesized:

H5: Social Innovativeness negatively moderates the positive relationship between customer satisfaction and customer loyalty

Based on the hypotheses, initial research model is given in Figure 1.

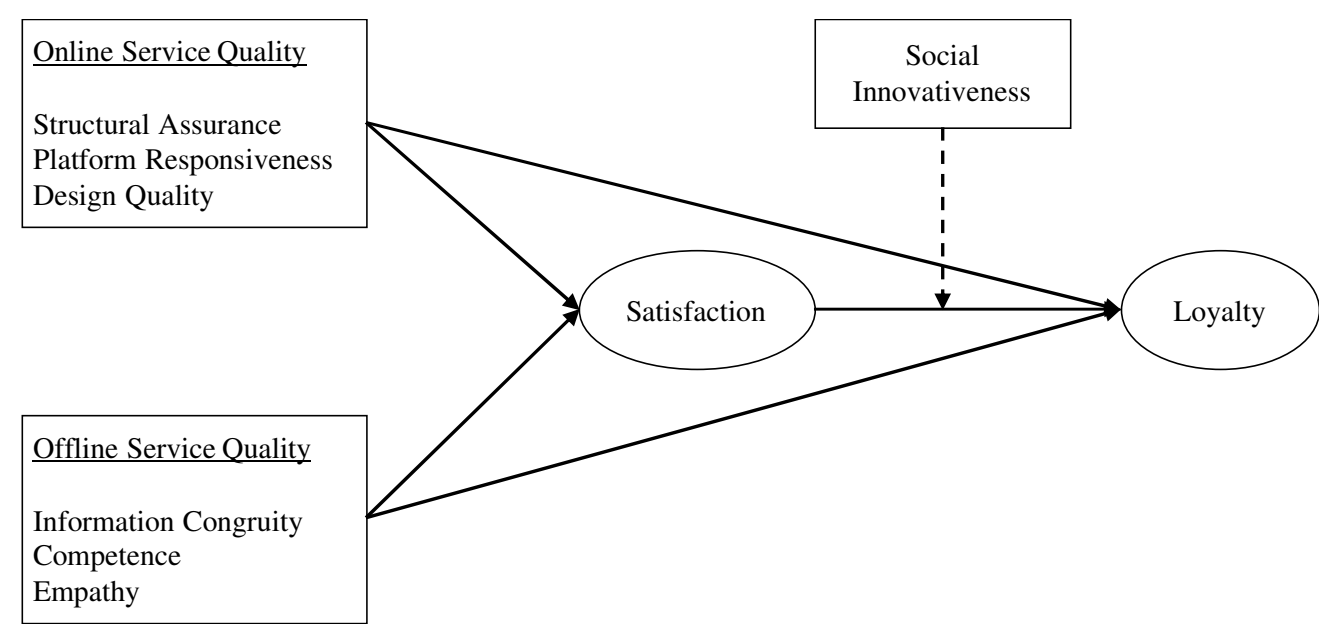

Figure 1. Research Model 


\section{METHODOLOGY}

\subsection{Questionnaire Design and Measurement}

The questionnaire design comprised three sections. Firstly, offline service quality (information congruity, competence, and empathy) and online service quality (structural assurance and platform responsiveness) adapted from Cheng et al. (2018). Due to the aesthetic factor that is now crucial in mobile apps based service (Heo \& Kim, 2017), we incorporated Design Quality in the SQ dimensions.

Structural assurance is composed by the safeguards, legal assurance, encrypted technology, transaction security. Platform responsiveness is composed by an immediate response, smooth process (without jam), and the promptness of the platform. Apps design quality is composed by the apps aesthetic, ease of use and simplicity. Information congruity is composed by the matching, consistency, and in line between the description in platform and what it showed. Competence is composed by the driver's competency, customer's confident and reliability of the driver. Lastly, empathy is composed by driver's best interest at heart, willingness to help and understand the user's need.

Secondly, customer satisfaction, loyalty that seized the customer's post-adoption attitude and behavior, and Social innovativeness that is composed by willingness to impress others, preference to distinguish from others, among the first to own a new product. Thirdly, the demographic information captured respondents' profile such as Age, Gender, Education Level, and Monthly Income. At the beginning of the survey questionnaire, we included the screening question to confine the respondents to those who met our criteria only, those who have used OFA service.

A reflective model of three dimensions each was used to operationalize online and offline service quality by using items adapted from existing studies. OFA is a kind of sharing economy to which we use the sharing economy's instrument to operationalize it. Four items were used to measure Social Innovativeness (Vandecasteele \& Geuens, 2010), three items for Customer Satisfaction (Deng et al., 2010), and four items for customer attitudinal and behavioral loyalty (Deng et al., 2010). Respondents' responses were measured using Likert Scale, ranging from 1 (strongly disagree) to 7 (strongly agree).

\subsection{Sample and Data Analysis}

Due to the difficulties in defining the sampling frame, we employed purposive sampling. 227 usable responses from OFAs' customers in Malaysia were received. As shown in Table 1, the respondents of this study were mostly female at 60.79 percent or somewhat more than half of it. The majority of the respondents were below 25 years old (55.51\%) and 25 - 35 years old $(40.97 \%)$ and generally have attained a Bachelor's or Master's degree. Many of the respondents earned a monthly income of RM1000 and less.

Our 227-sample demonstrated that in the level of education, "graduate" are quite large number. At the same time, the respondents who earn less than RM1000 per month are dominant. It could be indicated by the situation where the respondents who completed the bachelor degree are straight pursuing master degree. They are possibly 
Table 1. Sample profile

\begin{tabular}{|c|c|c|}
\hline Variable & Frequency & Percentage $(\%)$ \\
\hline \multicolumn{3}{|l|}{ Gender } \\
\hline Male & 89 & 39.21 \\
\hline Female & 138 & 60.79 \\
\hline \multicolumn{3}{|l|}{ Age } \\
\hline$<=25$ & 126 & 55.51 \\
\hline $25-35$ & 93 & 40.97 \\
\hline $36-45$ & 7 & 3.08 \\
\hline $46-55$ & 1 & 0.44 \\
\hline \multicolumn{3}{|l|}{ Level of Education } \\
\hline High School or Less & 19 & 8.37 \\
\hline Undergraduate & 110 & 48.46 \\
\hline Graduate & 98 & 43.17 \\
\hline \multicolumn{3}{|l|}{ Monthly Income } \\
\hline Below 1000 & 118 & 51.98 \\
\hline $1001-3000$ & 52 & 22.91 \\
\hline $3001-5000$ & 33 & 14.54 \\
\hline $5001-10000$ & 21 & 9.25 \\
\hline 10000 and Above & 3 & 1.32 \\
\hline
\end{tabular}

not yet hired or have no working experience and generally financially depends on family support or scholarship. As the result, the group who earn less than RM1000 is quite large number. The statistical method used in this study is partial least squares path modeling (PLS-PM) using the statistical application program (STATCAL). Statcal is a website-based statistical application program designed using an $\mathrm{R}$ programming language in RStudio by Prana Ugiana Gio and Rezzy Eko Caraka (Sutiksno et al., 2018). STATCAL provides PLS-PM statistical methods (Gio et al., 2018). The PLS-PM statistical method at STATCAL uses the R PLS-PM package developed by Gaston Sanchez (Sanchez, 2013). This statistical model was used, because the objective of this study was primarily to identify the predictive model relevance of our conceptual framework, namely online service quality, offline service quality, customer satisfaction and social innovativeness on customer loyalty and to identify the magnitude and direction of the variance demonstrated by these constructs toward customer loyalty.

\section{RESULTS AND FINDINGS}

There are two stages of testing in PLS-PM that are first, testing the outer model or measurement model, and second, testing the inner model or structural model. In testing the outer model, it examines the relationship between each latent variable to the indicators (Caraka \& Sugiarto, 2017). While in the inner model testing, it proves the relationship between latent variables (Caraka et al, 2020). Some testing of the outer model includes testing loading values, Dillon Goldstein's rho (Dillon \& Goldstein, 1985), and crossloading. Table 2 presents the test results of the outer model for the first order.

Table 2. Outer model based on first ordrer

\begin{tabular}{ccc}
\hline $\begin{array}{c}\text { Latent } \\
\text { variable }\end{array}$ & Indicator & Loading \\
\hline & SA1 & 0.745 \\
SA & SA2 & 0.781 \\
& SA3 & 0.775 \\
& SA4 & 0.723 \\
PR & PR1 & 0.859 \\
& PR2 & 0.842 \\
& PR3 & 0.686 \\
ADQ & ADQ1 & 0.596 \\
& ADQ2 & 0.762 \\
IC & ADQ3 & 0.756 \\
& IC1 & 0.848 \\
COM & IC2 & 0.835 \\
& IC3 & 0.771 \\
& COM1 & 0.701 \\
EMP & COM2 & 0.881 \\
& COM3 & 0.835 \\
& EMP1 & 0.884 \\
& EMP2 & 0.851 \\
\hline
\end{tabular}

*SA $=$ Structural Assurance, $\mathrm{PR}=$ Platform Responsiveness, $\mathrm{ADQ}=$ Apps Design Quality, IC = Information Congruity, $\mathrm{COM}=$ competence, $\mathrm{EMP}=$ Empathy 
The loading value states the correlation between latent variables and the indicators. The higher the loading value, the more closely the correlation between latent variables and the indicators. A loading value of $>0.7$ is acceptable. Based on the results of loading value testing in Table 1 , it is known that the loading value for the PR3 indicator is $0.686<0.7$ and the loading value for the ADQ1 indicator is $0.596<0.7$, thus, the two indicators are eliminated from the analysis process. Then the loading value testing process is carried out again without involving PR3 and ADQ1 indicators. Table 2 presents the results of loading value testing without involving PR3 and ADQ1 indicators.

Table 3. Outer Model Testing After Elimination of PR3 and ADQ1 Indicators (First Order)

\begin{tabular}{|c|c|c|c|}
\hline $\begin{array}{c}\text { Latent } \\
\text { variable }\end{array}$ & Indicator & Loading & $\begin{array}{c}\text { Dillon } \\
\text { Goldstein's rho }\end{array}$ \\
\hline \multirow{4}{*}{ SA } & PF1 & 0.745 & \multirow{4}{*}{0.842} \\
\hline & PF2 & 0.781 & \\
\hline & PF3 & 0.775 & \\
\hline & PF4 & 0.723 & \\
\hline \multirow{2}{*}{ PR } & DQ1 & 0.900 & \multirow{2}{*}{0.895} \\
\hline & DQ2 & 0.900 & \\
\hline \multirow{2}{*}{ ADQ } & IQ2 & 0.822 & \multirow{2}{*}{0.806} \\
\hline & IQ3 & 0.822 & \\
\hline \multirow{3}{*}{ IC } & $\mathrm{IC} 1$ & 0.848 & \multirow{3}{*}{0.859} \\
\hline & IC2 & 0.835 & \\
\hline & IC3 & 0.771 & \\
\hline \multirow{3}{*}{ COM } & COM1 & 0.701 & \multirow{3}{*}{0.85} \\
\hline & COM2 & 0.881 & \\
\hline & COM3 & 0.835 & \\
\hline \multirow{3}{*}{ EMP } & EMP1 & 0.884 & \multirow{3}{*}{0.859} \\
\hline & EMP2 & 0.851 & \\
\hline & EMP3 & 0.714 & \\
\hline
\end{tabular}

Based on the results of loading value testing in Table 3, it is known that the loading value for all indicators $>0.7$, which means that the indicators are valid in terms of reflecting latent variables. Next is Dillon-
Goldstein's rho test. Dillon-Goldstein's rho value is used to test unidimensionality. Dillon-Goldstein's rho value that is $>0.7$ is seen as an indicator block considered as unidimensional. Based on the results of testing the Dillon-Goldstein's rho value in Table 3, it is known that all DillonGoldstein's rho values are $>0.7$, which means that each latent variable has good unidimensionality. The last test of the outer model is cross-loading.

In cross-loading testing, it compares loading values between indicators and latent variables, and loading values between indicators and other latent variables (Shaobo et al., 2018). In cross-loading testing, it is expected that the loading value between the indicator and the latent variable is higher, compared to the loading value between indicators and other latent variables (Caraka et al. 2021). Table 4 presents the results of cross-loading testing.

\begin{tabular}{|c|c|c|c|c|c|c|}
\hline Indicator & SA & PR & $\mathrm{ADQ}$ & IC & $\mathrm{COM}$ & EMP \\
\hline SA1 & $(0.745)$ & 0.254 & 0.036 & 0.393 & 0.295 & 0.212 \\
\hline SA2 & $(0.781)$ & 0.199 & 0.054 & 0.402 & 0.410 & 0.235 \\
\hline SA3 & $(0.775)$ & 0.225 & 0.053 & 0.393 & 0.319 & 0.237 \\
\hline SA4 & $(0.723)$ & 0.441 & 0.093 & 0.288 & 0.395 & 0.335 \\
\hline PR1 & 0.297 & $(0.900)$ & -0.047 & 0.339 & 0.315 & 0.296 \\
\hline PR2 & 0.362 & $(0.900)$ & -0.085 & 0.379 & 0.335 & 0.430 \\
\hline ADQ2 & 0.030 & -0.122 & $(0.822)$ & -0.043 & -0.023 & -0.086 \\
\hline ADQ3 & 0.098 & 0.001 & $(0.822)$ & 0.091 & 0.076 & 0.037 \\
\hline IC1 & 0.337 & 0.346 & -0.015 & $(0.848)$ & 0.472 & 0.356 \\
\hline IC2 & 0.434 & 0.439 & 0.077 & $(0.835)$ & 0.433 & 0.378 \\
\hline IC3 & 0.435 & 0.185 & 0.008 & (0.771) & 0.315 & 0.224 \\
\hline COM1 & 0.411 & 0.171 & 0.051 & 0.418 & (0.701) & 0.463 \\
\hline COM2 & 0.351 & 0.233 & -0.007 & 0.376 & $(0.881)$ & 0.508 \\
\hline COM3 & 0.388 & 0.460 & 0.041 & 0.428 & $(0.835)$ & 0.550 \\
\hline EMP1 & 0.262 & 0.365 & -0.077 & 0.325 & 0.600 & (0.884) \\
\hline EMP2 & 0.249 & 0.276 & 0.021 & 0.242 & 0.542 & $(0.851)$ \\
\hline EMP3 & 0.325 & 0.359 & -0.015 & 0.418 & 0.380 & $(0.714)$ \\
\hline
\end{tabular}

Based on the results of cross-loading testing in Table 3, the loading value between each indicator variable and its latent variables is higher, compared to other latent variables. So, we can escape the cross- 
loading. Next is the loading test for the second order of the outer model.

Based on the results of loading value testing in Table 5, the loading value for the $\mathrm{PR}$ indicator is $0.597<0.7$ and the loading value for the ADQ indicator is $0.297<0.7$, thus, the two indicators are eliminated from the analysis process. Then the loading value testing process is carried out again without involving PR and ADQ indicators. Table 6 presents the results of loading value testing without affecting PR and ADQ indicators.

Based on the results of loading value testing in Table 6, the loading value for all indicators is $>0.7$, which means that the indicators are valid in terms of reflecting latent variables. Likewise, from the results of testing the Dillon-Goldstein's rho value in Table 6, it is known that all DillonGoldstein's rho values are $>0.7$, which means that each latent variable has good unidimensionality. The last test of the outer model is cross-loading.

Based on the results of cross-loading testing in Table 7, the loading value between

Table 5. Outer Model Testing based on Second Order Value

\begin{tabular}{ccc}
\hline Latent variable & Indicator & Loading \\
\hline ONSQ & SA & 0.926 \\
ONSQ & PR & 0.597 \\
ONSQ & ADQ & 0.297 \\
OFSQ & IC & 0.804 \\
OFSQ & COM & 0.864 \\
OFSQ & EMP & 0.785 \\
SATIS & SAT1 & 0.856 \\
SATIS & SAT2 & 0.846 \\
SATIS & SAT3 & 0.810 \\
LOYAL & LOY1 & 0.812 \\
LOYAL & LOY2 & 0.844 \\
LOYAL & LOY3 & 0.750 \\
LOYAL & LOY4 & 0.816 \\
*ONSQ = Online Service Quality, OFSQ = Offline Service \\
Quality, SATIS $=$ Satisfaction, LOYAL = Loyalty
\end{tabular}

Table 6. Outer Model Testing After Elimination of $P R$ and $A D Q$ (Second Order

\begin{tabular}{cccc}
\hline $\begin{array}{c}\text { Latent } \\
\text { variable }\end{array}$ & Indicator & Loading & $\begin{array}{c}\text { Dillon } \\
\text { Goldstein's rho }\end{array}$ \\
\hline ONSQ & SA & 1 & 1 \\
OFSQ & IC & 0.8037 & \\
OFSQ & COM & 0.8637 & 0.8601 \\
OFSQ & EMP & 0.7848 & \\
SATIS & SAT1 & 0.8569 & \\
SATIS & SAT2 & 0.8479 & 0.876 \\
SATIS & SAT3 & 0.8074 & \\
LOYAL & LOY1 & 0.812 & \\
LOYAL & LOY2 & 0.8441 & 0.8823 \\
LOYAL & LOY3 & 0.75 & \\
LOYAL & LOY4 & 0.8153 & \\
*ONSQ $=$ Online Service Quality, OFSQ = Offline Service Quality, \\
SATIS $=$ Satisfaction, LOYAL = Loyalty
\end{tabular}

Table 7. Testing Outer Models based on Cross-Loading (Second Order)

\begin{tabular}{ccccc}
\hline Indicator & ONSQ & OFSQ & SATIS & LOYAL \\
\hline SA & $(1.000)$ & 0.536 & 0.558 & 0.470 \\
IC & 0.489 & $(0.804)$ & 0.459 & 0.427 \\
COM & 0.469 & $(0.864)$ & 0.420 & 0.408 \\
EMP & 0.335 & $(0.785)$ & 0.341 & 0.421 \\
SAT1 & 0.518 & 0.432 & $(0.857)$ & 0.505 \\
SAT2 & 0.474 & 0.416 & $(0.848)$ & 0.473 \\
SAT3 & 0.409 & 0.417 & $(0.807)$ & 0.652 \\
LOY1 & 0.423 & 0.376 & 0.598 & $(0.812)$ \\
LOY2 & 0.394 & 0.477 & 0.576 & $(0.844)$ \\
LOY3 & 0.284 & 0.392 & 0.410 & $(0.750)$ \\
LOY4 & 0.392 & 0.404 & 0.481 & $(0.815)$ \\
*SA = Structural Assurance, IC = Information Congruity, COM = \\
competence, EMP = Empathy, SATIS = Satisfaction, LOYAL = \\
Loyalty
\end{tabular}

each indicator variable and its latent variables is higher, compared to other latent variables. Therefore, the cross-loading test has passed.

\subsection{Inner Model Testing (Structural Model)}

After testing the outer model (measurement model), the inner model (structural model) is then tested. The inner model testing includes testing the 


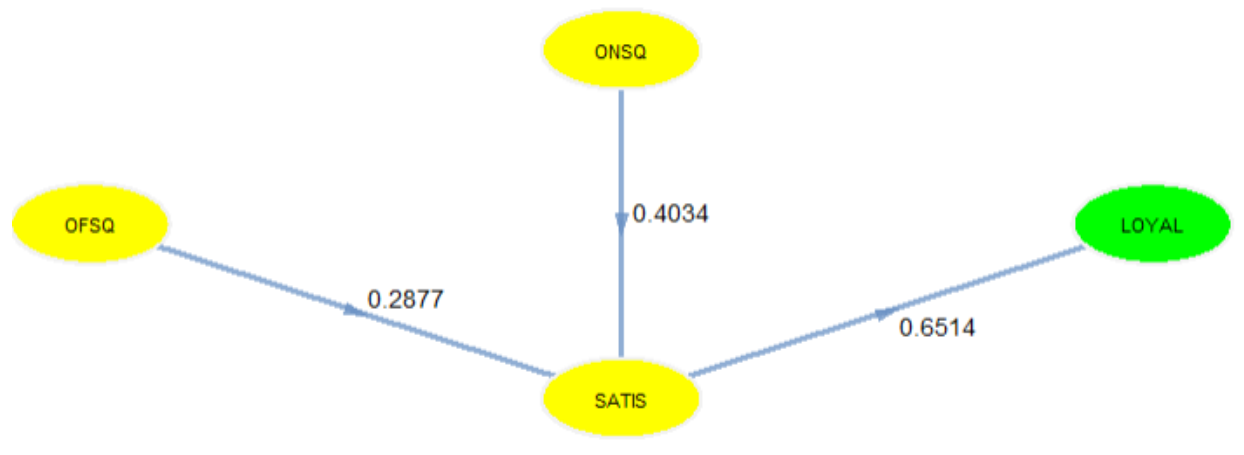

Figure 2. Direct and Indirect Testing Models

significance of direct effects, indirect effects, and moderation. Figure 1 is a model image that presents the path coefficient value. While Table 8 shows the results of testing the significance of direct effects.

Table 8. Direct Effect Significance Test

\begin{tabular}{clll}
\hline Relationship & $\begin{array}{l}\text { Paths } \\
\text { Original }\end{array}$ & $\begin{array}{l}\text { Paths. } \\
\text { perc.025 }\end{array}$ & $\begin{array}{l}\text { Paths. } \\
\text { perc.975 }\end{array}$ \\
\hline $\begin{array}{c}\text { ONSQ -> } \\
\text { SATIS }\end{array}$ & 0.403 & 0.272 & 0.525 \\
$\begin{array}{c}\text { OFSQ -> } \\
\text { SATIS }\end{array}$ & 0.288 & 0.176 & 0.406 \\
$\begin{array}{c}\text { SATIS -> } \\
\text { LOYAL }\end{array}$ & 0.651 & 0.578 & 0.730 \\
\hline
\end{tabular}

*ONSQ = Online Service Quality, OFSQ = Offline Service Quality, SATIS $=$ Satisfaction, LOYAL = Loyalty

An effect is said to be significant if the interval range paths.perc.025 and paths.perc. 975 do not contain zero values. While an effect is said to be insignificant if the interval range paths.perc.025 and paths.perc. 975 contain zero values. Based on the test results of the significant of the direct effects in Table 8, ONSQ has a positive effect on SATIS with path coefficient value of 0.403 and significant with intervals paths.perc. $025=0.272$ and paths.perc. $975=$ 0.525 that does not contain a zero value, OFSQ has a positive effect on SATIS with path coefficient value of 0.288 and significant with intervals paths.perc. $025=$ 0.176 and paths.perc. $975=0.406$ that does not contain a zero value and SATIS has a positive effect on LOYAL with path coefficient value of 0.651 and significant with intervals paths.perc. $025=0.578$ and paths.perc. $975=0.730$ that do not contain a zero value.

In addition, the study also tested the significance of indirect effects. Table 9 presents the test results of testing the significance of indirect effects. Moreover, Table 8 shows that ONSQ's indirect influence on LOYAL, through SATIS, is 0.263 . Based on the results of testing the significant, the interval paths.perc. $025=$ 0.172 and paths.perc. $975=0.348$ do not contain a zero value, which means that ONSQ significantly affects LOYAL, through SATIS.

Table 9. Indirect Effect Significance Test

\begin{tabular}{|c|c|c|c|}
\hline Relationship & Original & perc. 025 & perc.975 \\
\hline $\begin{array}{c}\text { ONSQ -> } \\
\text { SATIS -> } \\
\text { LOYAL }\end{array}$ & 0.263 & 0.172 & 0.348 \\
\hline $\begin{array}{c}\text { OFSQ -> } \\
\text { SATIS -> } \\
\text { LOYAL }\end{array}$ & 0.187 & 0.098 & 0.296 \\
\hline
\end{tabular}

*ONSQ $=$ Online Service Quality, OFSQ $=$ Offline Service Quality, SATIS $=$ Satisfaction, LOYAL $=$ Loyalty 
Figure 2 and Table 10 present the results of the SI significance test in moderating the effect of SATIS on LOYAL. Based on the results of testing the moderation in Table 10, in the SI*SATIS -> LOYAL row, we know the interval paths.perc. $025=1,238$ and paths.perc. $975=3.641$ do not contain a zero value, which means that SI significantly moderates the SATIS effect on LOYAL. The nature of the moderation effect is also found negative. Figure 3, gives the results of final moderation tests.

Table 10. The Significance of the Moderation Effect

\begin{tabular}{cccc}
\hline Relationships & $\begin{array}{c}\text { Paths } \\
\text { Original }\end{array}$ & $\begin{array}{c}\text { Paths. } \\
\text { perc.025 }\end{array}$ & $\begin{array}{c}\text { Paths. } \\
\text { perc. } 975\end{array}$ \\
\hline CI $->$ LOYAL & -0.086 & -0.169 & 0.001 \\
SATIS $->$ LOYAL & -1.816 & -2.945 & -0.577 \\
CI*SATIS $->$ LOYAL & 2.481 & 1.238 & 3.641 \\
\hline *I $=$ Social Innovativeness, SATIS $=$ Satisfaction, LOYAL = Loyalty
\end{tabular}

\section{DISCUSSION AND CONCLUSION}

The main objective of this study is to examine the relationship between the perceived service quality of online food aggregator service in Malaysia on customer satisfaction and customer loyalty by differentiating the online service quality and offline service quality. We also examine the mediating role of customer satisfaction and the moderating role of social innovativeness on customer satisfaction and loyalty linkage. We propose that when the perceived online service quality is high, the loyalty and customer satisfaction will be enhanced consequently. Likewise, the offline service quality-satisfaction-loyalty linkage, and thus hypotheses are supported. The aim to distinguished the service quality based on its characteristics, i.e: online and offline, is to identify its effect toward satisfaction and loyalty accordingly. Based on the analysis, it can be concluded that both online and offline perceived service quality significantly affect loyalty through customer satisfaction and stipulate evidence to support the hypothesis regarding the mediation effect proposed.

However, our finding is inconsistent with previous sharing economy research, in which they propose that customer satisfaction acts as partial mediator to the service quality and loyalty linkage. For instance, Cheng et al. (2018) suggests that customer satisfaction partially mediate the relationship between offline service quality and loyalty and claims that there is an indirect relationship between online service quality, satisfaction and loyalty. This is how our study complement

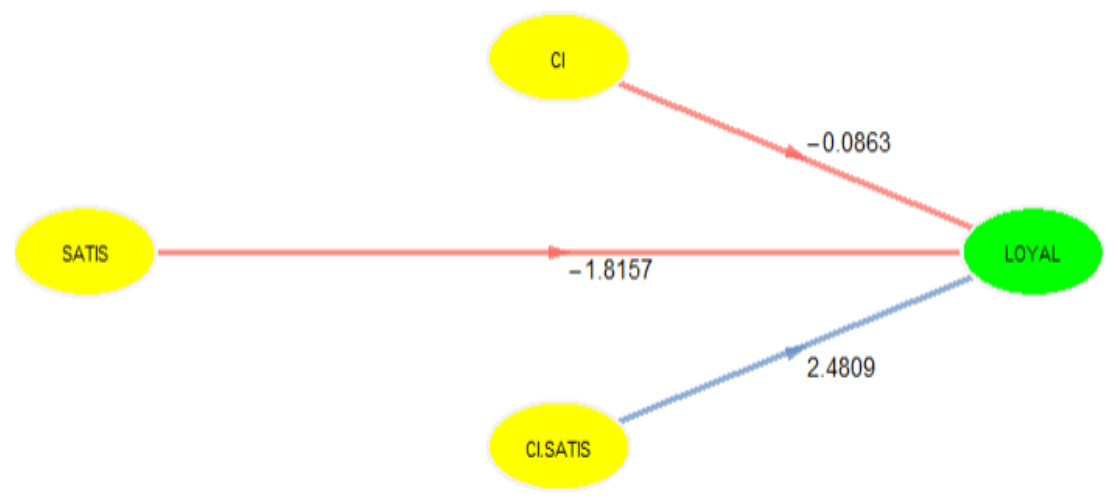

Figure 3. Moderation Testing 
theoretically to the service quality literature. As the prior study exhibits the distinctive effect of online and offline service quality, this research however validates that there is no difference effect between online service quality and offline service quality toward satisfaction and loyalty. Thus, future service quality research in sharing economy is suggested to measure the construct simultaneously as a multidimensional construct (Benoit et al., 2017).

Given the importance of sharing economy determined OFA's service quality in attaining customer loyalty, the OFA's customer perception regarding the service requires further explanation. The unique nature of OFA allows the adaptation of the existing model in capturing service quality, especially given the scant literature of OFA service quality, particularly in Malaysia. Therefore, our study contributes to this theoretical gap by expanding the understanding pertaining to the online and offline attributes of service quality.

Another contribution of this study is by providing its evidence on the dynamic relationship between customer satisfaction and customer loyalty. As proposed in H5, interestingly social innovativeness was found negatively moderates the effect of customer satisfaction on customer loyalty. For instance, the linkage between customer satisfaction and customer loyalty is strengthened when the customer was lack of social innovativeness. It suggests that the value of customer satisfaction and customer loyalty also depends on the customer social innovativeness level. A socially innovative user is preferably enjoying a unique OFA service more (Lu, 2014), as it offers him/her a distinctive value. In Malaysia, since OFA service is consider new and the service providers are few, the customer with high social innovativeness may feel unique and different when they experience it. However, one day this service will be common and reach the maturity. The service will be no longer considered as a new or innovative. Consequently, their switching behavior may come easily. Therefore, management of OFA players should consider customer social innovativeness status in treating customer since the customer satisfaction and loyalty may easily decrease when the customer is high in social innovativeness.

Our study also contributes to the practical. The finding shows that service quality is of a vast importance for service company. Our proposed model may become the reference and give the theoretical viewpoint, especially those service company engaged in sharing economy in order to improve the customer level of satisfaction and loyalty. Moreover, we advise that online and offline service quality may not distinctively implemented, the online and offline service should be performed aggregately, i.e: platform and riders, and support each other in order to maintain customer positive response. The apps security and protection, platform functioning, jointly with the simplicity usage of the apps are among the foremost focus in order to strengthen the quality of online service. To make it successful, the role of delivery phase is just as crucial. The information match between apps and what it showed, the driver's competency and willingness to deliver the service with best interest, will determine the customer's response. Therefore, the offline factors could also become the fundamental elements to better the OFA's service performance (Shao et al., 2020). In addition, the consumer's repurchasing behavior is of the factors for the service firms to sustain in the market (Orel \& Kara, 2014). Therefore, this research 
findings suggest in sharing economy determined OFA, service providers need to succeed in attaining customer satisfaction first before they can experience the ultimate goal of acquiring customer loyalty.

This study is not without limitation. As the data are obtained in Malaysia, the results may not be generalized in other countries. Future research can be conducted in different countries by considering other variables in order to expand our understanding of online food aggregator. Besides, considering Malaysia consists of many races, there is a tendency that customer behavior is subject to the social culture. Research investigating the role of social culture in customer behavioral consequences might be a fruitful topic.
Moreover, in terms of the mediation, the role of customer satisfaction as the mediator is found to be full-mediation. However, other possible mediators might exist in the service quality-loyalty linkage due to the dynamic nature. Therefore, future researches should be examining other prospective consequences in explaining the service quality and customer loyalty relationship, e.g: trust, perceived risk and habit. Lastly, since social innovativeness is one of many other personal motivations, other possible moderators need further investigations, such as hedonic and utilitarian motivations. Future studies will use H-Likelihood (Caraka, et al., 2020) in Structural equation models (Lee et al., 2017) (Jin et al., 2018).

\title{
ИСТРАЖИВАЫЕ ОНЛАЈН УСЛУГЕ АГРЕГАТОРА ХРАНЕ (ОАН): ДА ЛИ СЕ РАЗЛИКУЈУ ОНЛАЈН И ОФЛАЈН КВАЛИТЕТ УСЛУГА?
}

\author{
Yusra, Rezzy Eko Caraka, Arawati Agus, Ahmad Azmi Mohd Ariffin, \\ Prana Ugiana Gio, Rung Ching Chen, Youngjo Lee
}

Извод

Са појавом економија дељења, начин на који купац доживљава услугу помера се ка комбинацији услуге ван мреже и на мрежи. Пресудна је потреба да пружалац услуга разуме њену природу као и одговарајуће аспекте у вези са њеним карактеристикама. Претходна истраживања потврдила су утицај перцепције квалитета услуге на мрежи и ван ње на задовољство и лојалност купаца. Међутим, с препознатљивим димензијама квалитета ОАН услуге, њени ефекти на задовољство купаца, улога друштвене иновативности на задовољство купаца, као и повезаност са лојалношћу остају неистражени. Стога ова студија покушава да истражи наведене везе, користећи податке добијене од купаца ОАН-а у Малезији. Примењено је циљано узорковање и потом анализирано 227 прикупљених одговора, коришћењем делимичног моделовања парцијалних путања заснованих на варијанси. Резултати потврђују директан ефекат квалитета услуге на мрежи и ван ње на лојалност купаца и потпуну улогу посредовања у задовољству купаца. Поред тога, утврђено је да друштвена иновативност негативно утиче на задовољство купаца и однос лојалности. Такође се у раду дискутије о импликацијама и доприносу студије.

Кључне речи: квалитет услуге на мрежи, квалитет услуге ван мреже, мрежни агрегатор хране, задовољство купаца, лојалност купаца, друштвена иновативност 


\section{ACKNOWLEDGMENT}

This research in part of Sekolah Tinggi Ilmu Ekonomi Sabang (STIES), Banda Aceh. This research in part of Ministry of Science and Technology Taiwan under grant [MOST-107-2221-E-324-018-MY2] and [MOST-106-2218-E-324-002].This research in part of National Research Foundation of Korea under grants [NRF2019R1A2C1002408].

\section{References}

Ahn, J.A., \& Seo, S. (2018). Consumer responses to interactive restaurant selfservice technology (IRSST): The role of gadget-loving propensity. International Journal of Hospitality Management, 74, 109 121.

Belk, R. (2014). You are what you can access: Sharing and collaborative consumption online. Journal of Business Research, 67 (8), 15951600.

Benoit, S., Baker, T.L., Bolton, R.N., Gruber, T., \& Kandampully, J. (2017). A triadic framework for collaborative consumption (CC): Motives, activities and resources \& capabilities of actors. Journal of Business Research, 79, 219227.

Brady, M.K., \& Cronin Jr, J.J. (2001). Some New Thoughts on Conceptualizing Perceived Service Quality: A Hierarchical Approach. Journal of Marketing, 65 (3), 34 49.

Caraka, R.E., \& Sugiarto, S. (2017). Path Analysis Terhadap Faktor-Faktor Yang Mempengaruhi Prestasi Siswa. Jurnal Akuntabilitas Manajemen Pendidikan, 5 (2), 212219.

Caraka, R.E., Chen, R.C., Lee, Y., Noh, M., Toharudin, T., Pardamean, B., \& Saputra,
A. (2020). Variational Approximation Multivariate Generalized Linear Latent Variable Model in Diversity Termites Riau and Peninsular Malaysia. Sylwan, 164 (1). $161-77$.

Caraka, R.E., Lee,Y., Chen.R.C., \&Toharudin,T. (2020). Using Hierarchical Likelihood towards Support Vector Machine: Theory and Its Application. IEEE Access, doi: 10.1109/ACCESS.2020.3033796.

Caraka, R.E., Chen, R.C., Lee, Y., Toharudin, T. Rahmadi, C., Tahmid, M., \& Achmadi, A.S. (2021). Using Multivariate Generalized Linear Latent Variable Models to Measure the Difference in Event Count for Stranded Marine Animals. Global Journal of Environmental Science and Management, 7 (1), 117-130.

Caruana, A. (2002). Service loyalty: The effects of service quality and the mediating role of customer satisfaction. European Journal of Marketing, 36 (7/8), 811828.

Cheng, X., Fu, S., \& Vreede, G.-J. De. (2018). A mixed method investigation of sharing economy driven car-hailing services: Online and offline perspectives. International Journal of Information Management, 41 (10), 5764.

Cho, M., Bonn, M.A., \& Justin, J. (2018). Differences in perceptions about food delivery apps between single-person and multi-person households. International Journal of Hospitality Management, 7, 108116.

Chuah, S. H.-W., Rauschnabel, P.A., Marimuthu, M., Thurasamy, R., \& Nguyen, B. (2017). Why do satisfied customers defect? A closer look at the simultaneous effects of switching barriers and inducements on customer loyalty. Journal of Service Theory and Practice, 27 (3), 616641.

Cronin, J.J., Brady, M.K., \& Hult, G.T. M. 
(2000). Assessing the effects of quality, value, and customer satisfaction on consumer behavioral intentions in service environments. Journal of Retailing, 76 (2), 193218.

Deng, Z., Lu, Y., Wei, K.K., \& Zhang, J. (2010). Understanding customer satisfaction and loyalty: An empirical study of mobile instant messages in China. International Journal of Information Management, 30 (4), 289300.

Dillon, W.R. \& Goldstein, M. (1985). Multivariate Analysis. Methods and Applications. Geological Magazine, 122 (3), 310-320.

Dick, A.S., \& Basu, K. (1994). Customer Loyalty: Toward an Integrated Conceptual Framework. Journal of the Academy of Marketing Science, 22 (2), 99113.

Dillon, W.R., \& Goldstein, M. (1985). Multivariate Analysis. Methods and Applications. Geological Magazine, 122 (3), 310.

Gio, P.U., Caraka, R.E., Sutiksno, D.U. \& Ansari, S.A. (2018). Analisis Hubungan antara Variabel Kategori dengan STATCAL, SPSS dan Minitab (1re éd.). Medan. Universitas Sumatera Utara.

Heo, J.-Y., \& Kim, K.-J. (2017). Development of a scale to measure the quality of mobile location-based services. Service Business, 11 (1), 141159.

Heo, J., Lim, C. \& Kim, K. (2017). Scales for measuring mobile service quality: a literature review and identification of key dimensions. Int. J. Services and Operations Management, 27 (4), 524548.

Huang, E.Y., Lin, S.-W., \& Fan, Y.-C. (2015). M-S-QUAL: Mobile service quality measurement. Electronic Commerce Research and Applications, 14 (2), 126142.

Hult, G.T.M., Sharma, P.N., Morgeson, F.V., \& Zhang, Y. (2019). Antecedents and
Consequences of Customer Satisfaction : Do They Differ Across Online and Offline Purchases? Journal of Retailing, 95 (1), 10 23.

Shaobo, J., Noh, M., \& Lee, Y. (2018). "H-Likelihood Approach to Factor Analysis for Ordinal Data." Structural Equation Modeling 25 (4). 530-40.

Jin, S., Noh, M. \& Lee, Y. (2018). Hlikelihood approach to factor analysis for ordinal data. Structural Equation Modeling: A Multidisciplinary Journal, 25(4), pp.530540.

Joia, L.A., \& Altieri, D. (2018). Antecedents of continued use intention of ehailing apps from the passengers' perspective. Journal of High Technology Management Research, 29 (2) 204-215.

Juwaheer, T.D. (2004). Exploring international tourists' perceptions of hotel operations by using a modified SERVQUAL approach - a case study of Mauritius. Managing Service Quality: An International Journal, 14(5), 350364.

Kapoor, A.P., \& Vij, M. (2018). Technology at the dinner table: Ordering food online through mobile apps. Journal of Retailing and Consumer Services, 43, 342 351.

Kuo, Y., Wu, C., \& Deng, W. (2009). The relationships among service quality, perceived value, customer satisfaction, and post-purchase intention in mobile valueadded services. Computers in Human Behavior, 25 (4), 887896.

Lee, Y., Rönnegård, L., \& Noh, M. (2017). "Double HGLMs - Using the Dhglm Package." In Data Analysis Using Hierarchical Generalized Linear Models With R. New York, US: Chapman and Hall/CRC.

Lu, J. (2014). Are personal innovativeness and social influence critical to continue with 
mobile commerce? Internet Research, 24 (2), 134159.

Makanyeza, C., \& Chikazhe, L. (2017). Mediators of the relationship between service quality and customer loyalty: Evidence from the banking sector in Zimbabwe. International Journal of Bank Marketing, 35 (3), 540556.

Mittal, B. (2016). Retrospective: why do customers switch? The dynamics of satisfaction versus loyalty. Journal of Services Marketing, 30 (6), 569575.

Oliver, R.L., (1980). A Cognitive Model of the Antecedents and Consequences of Satisfaction Decisions. Journal of Marketing Research, XVII, 460469.

Orel, F.D., \& Kara, A. (2014). Supermarket self-checkout service quality, customer satisfaction, and loyalty: Empirical evidence from an emerging market. Journal of Retailing and Consumer Services, 21 (2), 118129.

Parasuraman, A., Zeithaml, V.A., \& Malhotra, A. (2005). E-S-Qual: A MultipleItem Scale for Assessing Electronic Service Quality. Journal of Service Research, 7 (3), 213233.

Parasuraman, A., Zeithaml, V.A., \& Berry, L.L. (1985). A Conceptual Model of Service Quality and Its Implications for Future Research. American Marketing Association, 49 (4), 4150.

Parasuraman, A., Zeithaml, V.A., \& Berry, L. L. (1988). SERVQUAL: a multiple-item scale for measuring consumer perceptions of service quality. Journal of Retailing, 64 (1), 1240.

Park, S., Yi, Y., \& Lee, Y. (2018). Heterogeneous dimensions of SERVQUAL. Total Quality Management \& Business Excellence, 0(0), 127.

Priporas, C.-V., Stylos, N., Rahimi, R., \& Vedanthachari, L.N. (2017). Unraveling the diverse nature of service quality in a sharing economy: A social exchange theory perspective of Airbnb accommodation. International Journal of Contemporary Hospitality Management, 29 (9), 22792301.

Purani, K., Kumar, D.S., \& Sahadev, S. (2019). e-Loyalty among millennials: Personal characteristics and social influences. Journal of Retailing and Consumer Services, 48, 215223.

Roos, D., \& Hahn, R. (2017). Understanding Collaborative Consumption: An Extension of the Theory of Planned Behavior with Value-Based Personal Norms. Journal of Business Ethics, 158, 679-697.

Sadik-Rozsnyai, O., \& Bertrandias, L. (2019). New technological attributes and willingness to pay: the role of social innovativeness. European Journal of Marketing. 53(6), 1099-1124.

Salameh, A.A.M., Ahmad, H., Zulhumadi, F., \& Abubakar, F.M. (2018). Relationships between system quality, service quality, and customer satisfaction: M-commerce in the Jordanian context. Journal of Systems and Information Technology, 20 (1), 73102.

Sanchez, G. (2013) PLS Path Modeling with R, Trowchez Editions. Berkeley, 2013. (http://www.gastonsanchez.com/PLS Path Modeling with R.pdf).

Santoso, A.S., \& Nelloh, L.A.M. (2017). User Satisfaction and Intention to Use Peerto-Peer Online Transportation: A Replication Study. Procedia Computer Science, 124, 379 387.

Setó-Pamies, D. (2012). Customer loyalty to service providers: examining the role of service quality, customer satisfaction and trust. Total Quality Management \& Business Excellence, 23 (11/12), 12571271.

Shah, N.U., Hashim, N.M.H.N., \& Omar, N.A. (2018). Credence and personal factors 
as a direct cause of brand extension evaluation: Does perceived fit matter? Malaysian Journal of Consumer and Family Economics, 21, 119.

Shao, Z., Li, X., Guo, Y., \& Zhang, L. (2020). Influence of service quality in sharing economy: Understanding customers' continuance intention of bicycle sharing. Electronic Commerce Research and Applications, 40, 100944.

Suhartanto, D., Ali, M.H., Tan, K.H., \& Sjahroeddin, F. (2018). Loyalty toward online food delivery service: the role of eservice quality and food quality. Journal of Foodservice Business Research, 22 (1), 8197.

Sutherland, W., \& Jarrahi, M.H. (2018). The sharing economy and digital platforms : A review and research agenda. International Journal of Information Management, 43, 328 341.

Sutiksno, D. U., Gio, P. U., Caraka, R. E., \& Ahmar, A. S. (2018). Brief Overview of STATCAL Statistical Application Program. Communication presen in Journal of Physics: Conference Series, 1028, 012244.

Vandecasteele, B., \& Geuens, M. (2010). Motivated Consumer Innovativeness: Concept, measurement, and validation. International Journal of Research in Marketing, 27 (4), 308318.

Vesel, P., \& Zabkar, V. (2009). Managing customer loyalty through the mediating role of satisfaction in the DIY retail loyalty program. Journal of Retailing and Consumer Services, 16 (5), 396406.

Yeo, V.C.S., Goh, S., \& Rezaei, S. (2017). Consumer experiences, attitude and behavioral intention toward online food delivery (OFD) services. Journal of Retailing and Consumer Services, 35, 150162.

Yusra, Y., \& Agus, A. (2018). The influence of Perceived Service Quality towards Customer Satisfaction and Loyalty in Airasia Self Check-in System. Journal of Social Sciences Research, 2 (Special Issue), 766775.

Yusra, Y., \& Agus, A. (2020). The influence of online food delivery service quality on customer satisfaction and customer loyalty: the role of personal innovativeness. Journal of Environmental Treatment Techniques, 8 (1), 612.

Zeithaml, V.A., Berry, L.L., \& Parasuraman, A. (1996). The Behavioral Consequences of Service Quality. Journal of Marketing, 60 (2), 3146. 